Reprod. Nutr. Dévelop., 1982, 22 (1 B), 193-200.

\title{
Influence of dietary essential fatty acid level on fatty acid composition in peripheral nerve and muscle
}

\author{
Marion PATURNEAU-JOUAS*, G. DURAND**, A. NOUVELOT*** \\ M. MASSON*, J. M. BOURRE* \\ * Laboratoire de Neurochimie, INSERM U. 134, CNRS, ERA 421 \\ Hôpital de la Salpêtrière, 75651 Paris Cedex 13, France \\ * Station de Recherches de Nutrition, INRA, \\ 78350 Jouy-en-Josas, France \\ ** Laboratoire de Physiopathologie des Lipides, Faculté de Pharmacie, \\ 3 rue du Pr. Laguesse, 59000 Lille, France
}

Summary. - Two groups of rats of different lines were divided into two lots. The four lots, whose dams received a fat-controlled diet, were fed with diets containing different levels of essential unsaturated fatty acids, namely linoleic (18:2 (n-6)) and linolenic $(18: 2(n-3))$ acid, in the oil. Nerve and muscle fatty acids were analyzed at adulthood. When the linolenic acid level was less than $0.6 \mathrm{p} .100$ of the total fatty acids in the diets (peanut oil and sunflower oil), the level of long-chain polyunsaturated fatty acids (PUFA) of the (n-3) series decreased. This decrease was associated with an increase in the PUFA of the (n-6) series. Total PUFA $((n-3)+(n-6))$ remained similar in the same group of rats, whatever the diet.

On the contrary, when dietary linolenic acid reached 7.6 p. 100 (soya oil) or 8.5 p. 100 (rapeseed oil) of the total fatty acids, in the presence of a very high linoleic acid level, the PUFA of the (n-6) series decreased and that of the (n-3) series increased in nerve and especially in muscle. It appears that preferential PUFA biosynthesis from linolenic acid occurred when the ratio $(n-6) /(n-3)$ was low enough in the dietary oil.

\section{Introduction.}

Many membrane properties are related to membrane fatty acid composition. The characteristics of each particulate fatty acid give it the particulate aptitude to move in space or to join neighboring molecules. Long hydrophobic chains increase the forces of intermolecular attraction (Chapman, 1973; Dowben, 1969) ; when a membrane is rich in very long-chain fatty acids, its cohesion, especially in its inner non-polar region, is increased in the areas occupied by the side chains. Such a membrane is found in the nervous system : the myelin sheath is particularly rich in sphingolipids containing very long-chain fatty acids (Baumann et al., 1973 ; Hansen and Clausen, 1969 ; O'Brien and Sampson, 1965). 
On the contrary, the presence of monounsaturated or polyunsaturated fatty acids (PUFA) enhances membrane fluidity (Kimelberg and Papahadjopoulos, 1974), allowing facilitated ion transport (Papahadjopoulos et al., 1973) and increased membrane-bound enzyme activity (Coleman, 1973; Kimelberg and Papahadjopoulos, 1974 ; Papahadjopoulos et al., 1973). The enrichment in the unsaturated fatty acid (UFA) content of the cell membrane may be an adaptive mechanism in cold resistance (Goldman, 1975) as it is in muscle as a result of endurance training (Thomas et al., 1977). Another nervous membrane, the synaptosomal membrane, contains a high proportion of polyunsaturated fatty acids (Kishimoto et al., 1969). This observation may be related to the highly specialized exchange mechanisms operating at the level of the synapses.

In the peripheral nervous system (Cassagne et al., 1980) as in the central nervous system (Bourre et al., 1977 ; Bourre, 1980 ; Paturneau-Jouas et al., 1976 a, b ; Pollet et al., 1973), saturated and monounsaturated fatty acids are mainly synthesized by endogenous enzymatic systems. However, they may also be taken up by the brain from the blood and incorporated into lipids (Dhopeshwarkar and Mead, 1973 ; Gozlan-Devillière et al., 1976). Indeed, this in the only way the brain obtains the essential fatty acids, $18: 2(n-6)$ (linoleic acid) and $18: 3$ (n-3) (linolenic acid), which mammals cannot synthesize. PUFA, especially $20: 4(n-6)$ (arachidonic acid) and $22: 6(n-3)$ (docosahexaenoic acid), are removed from the blood and incorporated into the brain lipids (Hassam and Crawford, 1976; Sinclair and Crawford, 1972). The (n-6) series can be synthesized from $18: 2$ or the $(n-3)$ series from $18: 3$ through elongation desaturation mechanisms in the liver. Much less is known of the effects of lowering linolenic acid than of lowering linoleic acid in the diet (Crawford et al., 1978 ; Leat, 1981).

Since PUFA are major components of nerve phospholipids and important constituents of muscle membrane, we attempted to determine the effect on the fatty acid profile of both peripheral nerve and muscle of varying the $n-6 / n-3$ ratio in the diet with a sufficient supply of the $(n-3)$ series precursor or a very low supply of $18: 3(n-3)$.

\section{Material and methods.}

\section{Animals and diet.}

Group 1. - Two lots of female rats were fed a semi-synthetic diet containing casein (18 p. 100), starch (30 p. 100), sucrose (36 p. 100), salt mixture (4 p. 100), agar-agar (2 p. 100), fat $(10$ p. 100) and vitamins. Lot $P$ received peanut oil and lot $R$ rapeseed oil. They were fed the experimental diet ad libitum during pregnancy. After birth, 8 pups were left with each dam and the treatment was continued on them throughout lactation and after weaning.

Group 2. - For 4 generations, female rats were fed a semi-synthetic diet containing 1 p. 100 sunflower oil. At the fourth generation and one week before mating, they were divided into two lots : lot $\mathrm{SU}$ which continued to receive the 
sunflower oil diet and lot $S$ which was fed a diet containing 1.15 p. 100 soya oil. After weaning, the treatment was continued on the young rats. The fatty acid composition of each dietary oil is given in table 1.

TABLE 1

Fatty acid composition of the dietary oils studied.

\begin{tabular}{|c|c|c|c|c|}
\hline \multirow[b]{2}{*}{ Fatty acid } & \multicolumn{2}{|c|}{ Group 1} & \multicolumn{2}{|c|}{ Group 2} \\
\hline & $\begin{array}{l}\text { Rapeseed } \\
\text { oil }\end{array}$ & $\begin{array}{c}\text { Peanut } \\
\text { oil }\end{array}$ & $\begin{array}{c}\text { Soya } \\
\text { oil }\end{array}$ & $\begin{array}{c}\text { Sunflower } \\
\text { oil }\end{array}$ \\
\hline $16: 0$ & 6.5 & 9.2 & 12.2 & 8.5 \\
\hline $16: 1$ & 0.2 & 0.1 & - & - \\
\hline $18: 0$ & 2.4 & 3.4 & 4.1 & 4.9 \\
\hline $18: 1$ & 50.1 & 48.4 & 23.4 & 22.4 \\
\hline $18: 2(n-6)$ & 25.9 & 30.2 & 52.7 & 63.7 \\
\hline $18: 3(n-3)$ & 8.5 & 0.2 & 7.6 & 0.5 \\
\hline $20: 0$ & 0.5 & 1.4 & - & - \\
\hline $20: 1$ & 1.7 & 1.2 & - & - \\
\hline $22: 0$ & 0.4 & 2.9 & - & \\
\hline $22: 1$ & 1.9 & - & - & - \\
\hline $22.6(n-3)$ & 2.0 & 1.6 & - & - \\
\hline $24: 0$ & - & 1.4 & - & - \\
\hline$\frac{18: 2(n-6)}{18: 3(n-3)}$ & 3.0 & 151.0 & 6.9 & 127.4 \\
\hline
\end{tabular}

\section{Lipid analysis.}

Adult animals were killed by cervical disruption and the sciatic nerve and quadriceps muscle quickly removed. The intact sciatic nerve and the muscle, homogenized in ice-cold water, were freeze-dried and the lipids extracted as previously described (Pollet et al., 1978). The fatty acids were analyzed by gasliquid chromatography using an open tubular column (carbowax $20 \mathrm{M}, 50 \mathrm{~m}$ long, $0.2 \mathrm{~mm}$ wide). Fatty acid concentrations were determined with a computer (ICAP 10, LTT).

\section{Results.}

Sciatic nerve fatty acid profiles from rats fed with rapeseed, peanut, soya or sunflower oil are shown in table 2 . Total long-chain fatty acids (LCFA) containing 20 carbon atoms or more and fatty acids of the $(n-6)$ and $(n-3)$ series are expressed as a percentage of the total fatty acids on the lower part of the table. As all essential fatty acid derivatives possess 20 carbon atoms or more, total PUFA was expressed as a percentage of LCFA. At least the respective parts of the $(n-6)$ and $(n-3)$ series in PUFA were calculated. 
TABLE 2

Fatty acid profile of nerve in rats fed experimental diets.

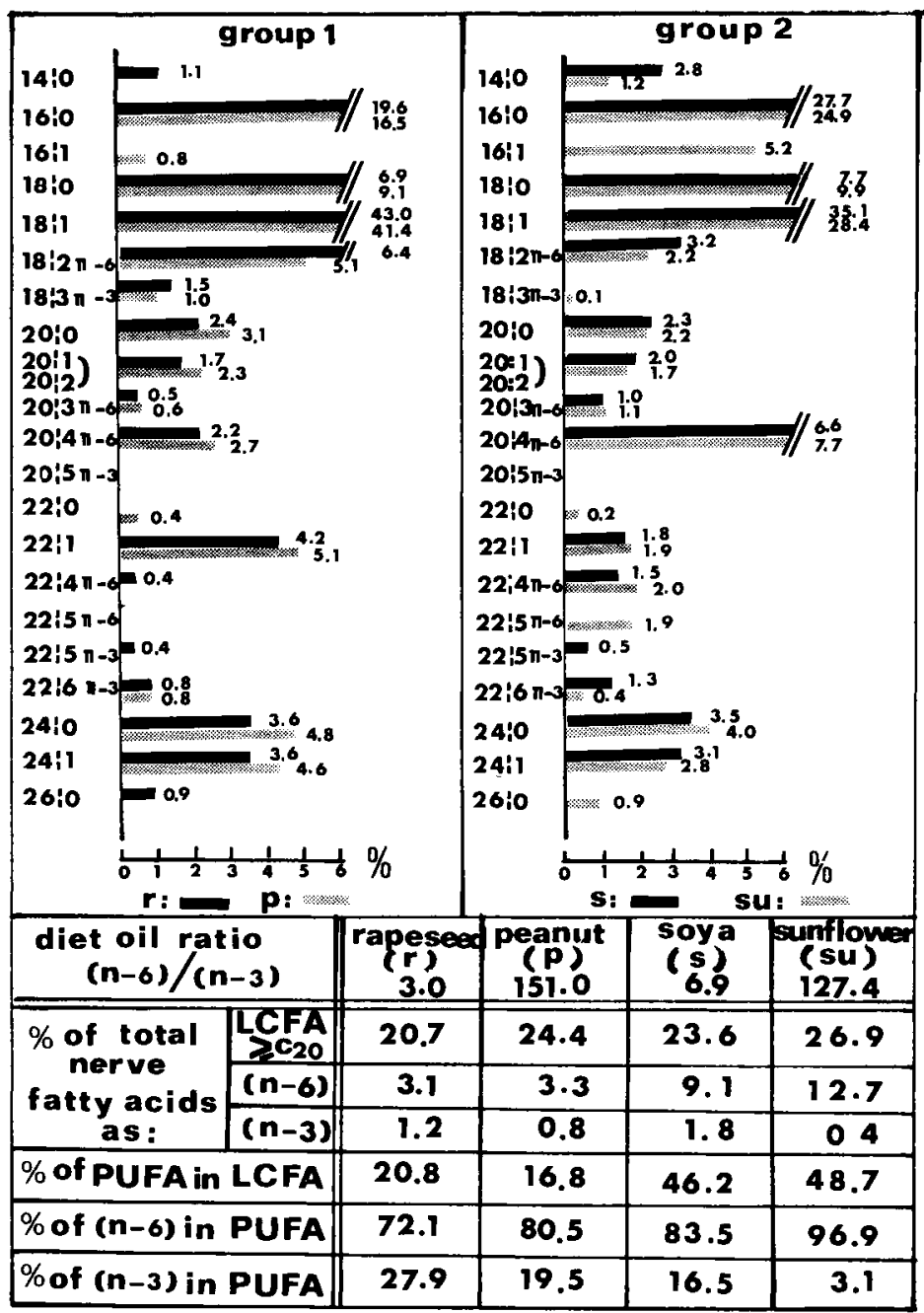

Muscle fatty acid profiles and the same calculations as for nerve are presented in table 3.

\section{Discussion.}

LCFA represents approximately $1 / 4$ of the fatty acids of each studied membrane. The level of LCFA decreased in both the nerve and the muscle of rats fed with rapeseed oil. 
TABLE 3

Fatty acid profile of muscle in rats fed experimental diets.

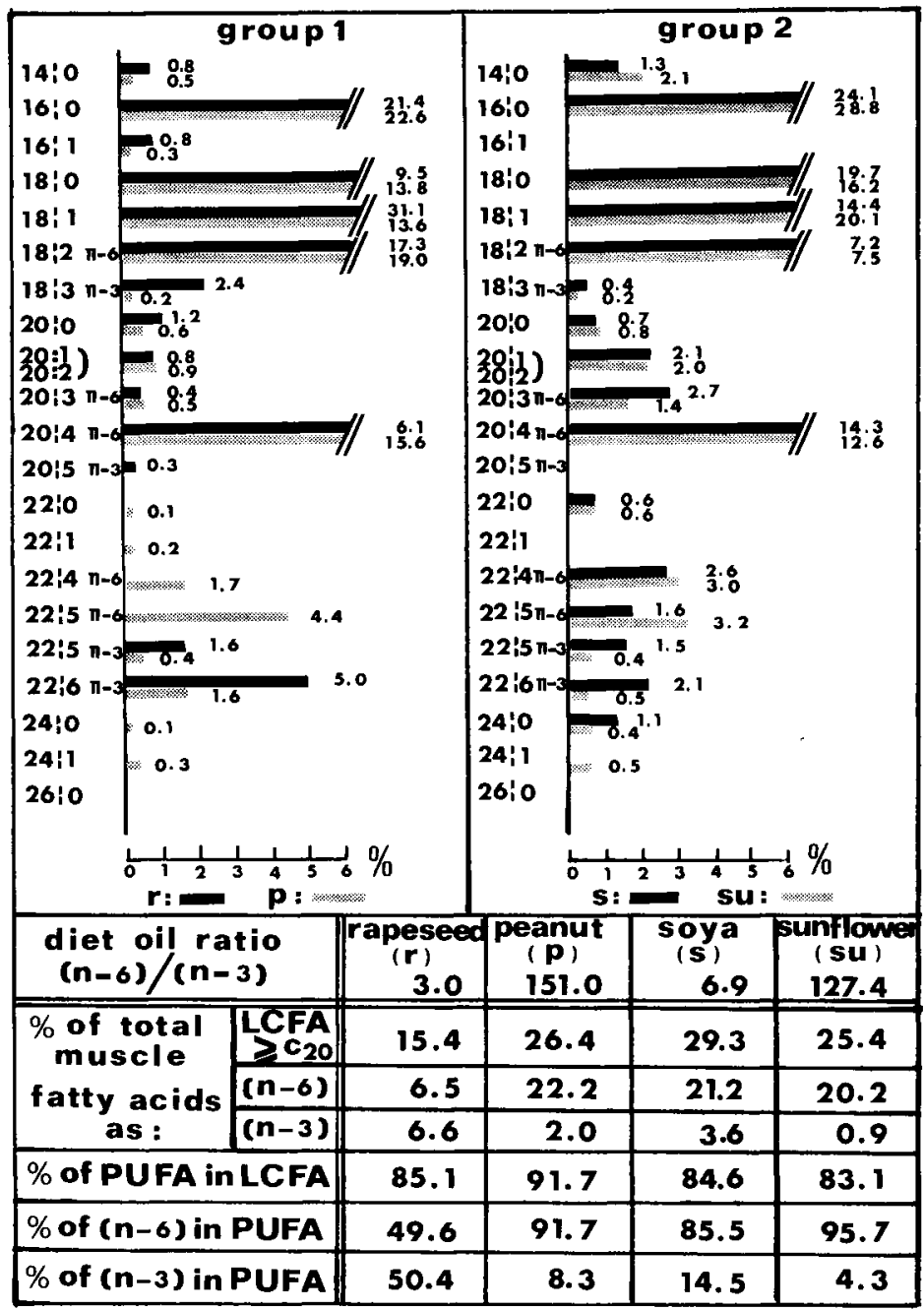

The fact that saturated and monounsaturated LCFA are major components of myelin may explain why the relative percentages of PUFA are much higher in muscle than in nerve. However, as previously shown in brain (Galli et al., 1971 ; Nouvelot et al., 1981 a, b) total PUFA - $(n-6)+(n-3)$ - remained relatively constant in the membranes of a same group of rats whichever diet they were fed.

In rats of group 1, rapeseed oil, which, has the lowest ratio of $(n-6) /(n-3)$ compared to peanut oil, was shown to induce a decrease of $(n-6)$ fatty acids and an increase of $(n-3)$ fatty acids in the membranes ; both these effects were much more evident in muscle than in nerve. The same, but less marked, alterations were 
observed in group 2 rats fed with the low-ratio soya oil or with sunflower oil. It is important to note that linoleic acid, $18: 2(n-6)$, predominated largely in the four different diets; thus, the increase in the $(n-3)$ LCFA is probably due to preferential PUFA biosynthesis from linolenic acid, $18: 3(n-3)$, when the dietary oil ratio, linoleic/linolenic acid, was low enough. This is particularly evident in the muscle of rats fed with the rapeseed oil : $22: 4(n-6)$ and $22: 5(n-6)$ were not detectable but the $22: 5(n-3)$ and $22: 6(n-3)$ levels increased.

Conversely, the linolenic acid deficiency in the peanut and sunfiower diets, in which $18: 3(n-3)$ represented less than 0.6 p. 100 of overall fatty acids, induced a large decrease in the level of PUFA ( $n-3)$ fatty acids.

In conclusion, although dietary linolenic acid deficiency has a marked effect (whose physiological significance remains to be determined) on fatty acid profiles of peripheral nerve and muscle, it is shown that the dietary essential fatty acid ratio itself is a key point in the regulation of long-chain polyunsaturated fatty acid biosynthesis. Further analysis of fatty acid composition in isolated lipids could provide information about the location of these alterations in the membranes of nerve and muscle.

$7^{e}$ Réunion du groupe Développement I.N.R.A. Nouzilly/Tours, 14-15 mai 1981.

Résumé. - Deux groupes de rats de souche différente ont été divisés chacun en deux lots. Les quatre lots de rats nouveau-nés issus de mère à l'alimentation contrôlée en graisses, ont été soumis à des régimes différant par la teneur des huiles en acides gras insaturés essentiels, I'acide linoléique $(18: 2(n-6))$ et l'acide linolénique $(18: 3(n-3))$. A l'âge adulte, les acides gras constituants du nerf et du muscle ont été analysés. Lorsque la quantité d'acide linolénique du régime est inférieure à $0,6 \mathrm{p} .100 \mathrm{du}$ total des acides gras (huiles $d^{\prime}$ arachide et de tournesol), la quantité d'acides gras polyinsaturés à longue chaîne (PUFA) de la série $(n-3)$ est très diminuée dans le nerf et le muscle. Cette diminution est compensée par une augmentation des PUFA de la série $(n-6)$; le total des PUFA $(n-3)+(n-6)$ restant constant quelle que soit I'huile de régime pour un même groupe de rats.

Par contre, lorsque la quantité d'acide linolénique de l'huile de régime atteint 7,6 p. 100 des acides gras totaux (huile de soja) ou 8,5 p. 100 (huile de colza Primor), le taux d'acide linoléique restant par ailleurs très élevé, il y a une diminution du taux des PUFA de la série $(n-6)$ et une augmentation des PUFA de la série $(n-3)$ dans le nerf et surtout dans le muscle. Il y a une biosynthèse préférentielle des PUFA à partir de l'acide linolénique $(18: 3(n-3))$ dès lors que le rapport $(n-6) /(n-3)$ des huiles du régime est suffisamment bas.

\section{References}

BAUMANN N. A., BOURRE J. M., JACQUE C. M., HARPIN M. L., 1973. Lipid composition of quaking mouse myelin : comparison with normal mouse myelin in the adult and during development. J. Neurochem., 20, 753-759.

BOURRE J. M., PATURNEAU-JOUAS M., DAUDU O., BAUMANN N., 1977. Lignoceric acid biosynthesis in the developing brain. Activities of mitochondrial acetyl-CoA-dependent synthesis and microsomal malonyl-CoA chain-elongating system in relation to myelination. Comparison between normal mouse and dysmyelinating mutants (quating and jimpy). Eur. J. Biochem., 72, 41-47. 
BOURRE J. M., 1980. Origin of aliphatic chains in brain. In : BAUMANN N. Neurological mutations affecting myelination. INSERM Symp., $\mathrm{N}^{\circ}$ 14, Elsevier/North Holland Biomedical Press, Amsterdam.

CASSAGNE C., DARRIET D., BOIRON F., LARROUQUERE-REGNIER S. BOURRE J. M. 1980. Fatty acid biosynthesis in the sciatic nerve from Trembler mouse. In: BAUMANN $\mathrm{N}$. Neurological mutations affecting myelination, INSERM Symp., No 14, Elsevier/North Holland Biomedical Press, Amsterdam.

CHAPMAN D., 1973. The role of fatty acids in myelin and other important brain structures, 31-57. Lipid, malnutrition and the developing brain. Ciba Found. Symp., Elsevier Ed, Amsterdam.

COLEMAN R., 1973. Membrane-bound enzymes and membrane ultrastructure. Biochim. biophys. Acta, 300, 1-30.

CRAWFORD M. A., HASSAM A. G., RIVERS J. P. W., 1978. Essential fatty acid requirements in infancy. Am. J. clin. Nutr., 31, 2181-2185.

DHOPESHWARKAR G. A., MEAD J. F., 1973. Uptake and transport of fatty acids into the brain and the role of blood-brain barrier system. Adv. Lipid Biochem., 11, 109-142.

DOWBEN R. M., 1969. Composition and structure of membranes, 1-38. In : DOWBEN R. M., Biological Membranes. Little Brown, Boston, Mass.

GALLI C., TRECIAK H., PAOLETTI R., 1971. Effects of dietary fatty acid composition of brain ethanolamine-phosphoglyceride : reciprocal replacement of $n-6$ and $n-3$ polyunsaturated fatty acids. Biochim. biophys. Acta, 248, 449-454.

GOLDMAN S. S., 1975. Cold resistance of brain during hibernation. III. Evidence of lipid adaptation. Am. J. Physiol., 228, 834-838.

GOZLAN-DEVILLIĖRE N., BAUMANN N., BOURRE J. M., 1976. Mouse brain uptake and metabolism of stearic acid. Biochimie, 58, 1129-1133.

HANSEN I. B., CLAUSEN J., 1969. Lipid composition of brain and serum of young rats in relation to age and diet. $Z$. Ernährungswiss, 9, 278-289.

HASSAM A. G., CRAWFORD M. A., 1976. The differential incorporation of labelled linolenic. $\gamma$-linolenic, dihomo- $\gamma$-linolenic and arachidonic acids into the developing rat brain. $J$. Neurochem., 27, 967-968.

KIMELBERG H. K., PAPAHADJOPOULOS D., 1974. Effects of phospholipid acyl chain fluidity, phase transitions, and cholesterol on $\left(\mathrm{Na}^{+}+\mathrm{K}^{+}\right)$stimulated adenosine triphosphate. J. biol. Chem., 249, 1071-1080.

KISHIMOTO Y., AGRANOFF B. W., RADIN N. S., BURTON R. M., 1969. Comparison of the fatty acids of lipids of subscellular brain fractions. J. Neurochem., 16. 397-404.

LEAT N. M. F., 1981. Man's requirement for essential fatty acids. Trends Biochem. Sciences, 6, IX-X.

NOUVELOT A., BOURRE J. M., SEZILLE G., DEWAILLY P., JAILLARD J., 1981 a. Polyunsaturated fatty acid alterations in brain phospholipids (EPG-CPG) during development from rats fed with peanut or rapeseed oil, taking into account differences between milk and maternal food. Ann. Nutr. Metab. (submitted).

NOUVELOT A., SEZILLE G., PATURNEAU-JOUAS M., DUMONT O., MASSON M., BOURRE J. M., 1981 b. Influence de la teneur en acide linolénique du régime maternel sur la composition en acides gras polyinsaturés des fractions subcellulaires au cours du développement cérébral chez le rat. Ann. Nutr. Metab. (submitted).

O'BRIEN J. S., SAMPSON E. L., 1965. Fatty acid and fatty aldehyde composition of the major brain lipids in normal human gray matter, white matter, and myelin. J. Lipid Res., 6, 545-551.

PAPAHADJOPOULOS D., COWDEN M., KIMELBERG H., 1973. Role of cholesterol in membranes : effects of phospholipid-protein interactions, membrane permeability and enzymatic activity. Biochem. biophys. Acta, 330, 8-26.

PATURNEAU-JOUAS M., BAUMANN N., BOURRE J. M., 1976 a. Biosynthèse des. acides gras dans les mitochondries de cerveau de souris en présence de malonyl-CoA ou d'acétylCoA. Biochimie, 58, 341-349.

PATURNEAU-JOUAS M., BAUMANN N., BOURRE J. M., $1976 \mathrm{~b}$. Elongation of palmityl-CoA in mouse brain mitochondria: comparison with stearyl-CoA. Biochem. biophys. Res. Commun., 71, 1326-1334. 
POLLeT S., BouRre J. M., ChaIX G., DAUDU O., BAUMANN N., 1973. Biosynthèse des acides gras dans les microsomes de cerveau de souris. Biochimie, 55, 333-341.

POLLET S., ERMIDOU S., LE SAUX F., MONGE M., BAUMANN N., 1978. Microanalysis of brain lipids : multiple two-dimensional thinlayer chromatography. J. Lipid Res., 19, 916-921.

SINCLAIR A. J., CRAWFORD M. A., 1972. The incorporation of linolenic acid and docosahexaenoic acid into liver and brain lipids of developing rats. FEBS Lett., 26, 127-129.

THOMAS T. R., LONDEREE B. R., GERHARDT K. O., GEHRKE C. W., 1977. Fatty acid profile and cholesterol in skeletal muscle of trained and untrained men. J. appl. Physiol. Respirat. environ. Exercise Physiol., 43, 709-713. 